Palliat Support Care. 2020 December ; 18(6): 754-756. doi:10.1017/S1478951520001030.

\title{
The Redeemer of Grand Street
}

\author{
William Breitbart, M.D. \\ Jimmie C Holland Chair in Psychiatric Oncology, Department of Psychiatry and Behavioral \\ Sciences, Memorial Sloan-Kettering Cancer Center, New York, NY
}

"Blackbird singing in the dead of night

Take these broken wings and learn to fly

All your life

You were only waiting for this moment to arise"McCartney and Lennon (1968)

\section{Bad faith-As if I never lived}

I died before I was born. Before I had the chance to realize that I existed. Before I had the chance to objectively contemplate myself. Before I had the experience, at age 11, to walk out of the collective mist, into the open field, and realize "I am." No chance to realize that I was no longer part of an undifferentiated state of being, but rather a separate, individual, unique human being. Before I was struck with the existential obligation of "Responsibility." The responsibility to create a life; a life that was unique to me. A life that was created by my choices, and values and authentic to me. A life to be lived to its fullest potential, with meaning, direction, attitude, and authenticity. In this time of the Global COVID-19 Pandemic of 2020, I've been reflecting on loss. This essay explores two very basic, personal losses that have been evoked by the "death salience" that has permeated our current global subconscious. The first loss is "the loss of the freedom to choose to create my own life rather than the imperative to become the redeemer of my parents who survived the Holocaust." It was clear that my one and only destiny was to be created into the person who would redeem my parents and justify their survival, when so many millions did not, through my life's impact on the world.

Close your eyes, and imagine a 4 year-old boy, living in an one bedroom apartment on Grand Street in the Lower East Side of Manhattan, with his parents Rose and Moishe. Rose was 14 years old when the Nazis invaded Poland. Moishe was 17. Their families were wiped out in the Holocaust; starving to death in hiding, carted off in cattle cars to Auschwitz and Treblinka. No one survived but the two of them. They found each other in the forests of Poland. Young Partisans, fighters, hidden in the woods, starving, ever vigilant for the Nazi or Ukrainian soldiers that would come upon them and extinguish their lives. They were second cousins. The forest floor was their bed. The stars and sky their blanket. They fell asleep in each other's embrace to stay warm. They needed each other to survive. A basis for love and

Author for correspondence: William Breitbart, Chairman, Jimmie C Holland Chair in Psychiatric Oncology, Department of Psychiatry and Behavioral Sciences, Memorial Sloan-Kettering Cancer Center, 641 Lexington Avenue, 7th Floor, New York, NY 10022, USA. breitbaw@mskcc.org. 
what would become marriage lasting 65 years. The war ended; abruptly, miraculously. They trekked across the Polish-German border to a refugee camp outside of Munich called Fahrenwald. They married there, sleeping in a bed borrowed from another married couple on their wedding night. Then the voyage in 1949 to America, New York, the Lower East Side, Grand Street. I was born several years later. A son; the first-born son. New life. New hope. They had the courage to live, the courage to love, the courage to hope, they still had the fire and the fight within them. As that 4 year-old boy I could not escape the reality that the Holocaust lived with us in that apartment on Grand Street. It didn't have a room of its own, it lived in every room, on every wall, in every picture and religious article saved from the Holocaust- my father's tallit or prayer shawl, the yellow felt star worn by my grandfather inscribed with the label "Jude." Death lived in every room as well. Death was in the air. I breathed the air of death daily; in the words and stories and the memories recounted of all who died in our families, and the millions more who died in the Shoah. Most poignant were all the young people, my parents age, who died before they had a chance to create and live their lives. All those who died before they were born- unlived lives. For me, at age 4, "Death" was real, very real, constant, and palpable. Death was not an abstraction. From the age of 4 on, I lost the ability to deny death. This is the second personal loss I explore here.

\section{The Redeemer}

As a child, every morning, when my mother would prepare breakfast, she would ask me the same question, "Why am I here?" The full question was really "Why am I here when everyone else was not? Why did I survive and everyone else I knew and loved died?" She had profound guilt that she had survived and virtually no one else had. Guilt seemed to be paramount, but as I look back at her experience and my father's experience, it was likely even more complex. It was likely not merely guilt. It was also a struggle with a sense of the world being meaningless. A struggle with the existence and the nature of a God who could allow the Holocaust to occur. "Why did God allow this? Was there a purpose, a plan, a destiny, a meaning?" Perhaps the one question my Mother should have directed towards me but didn't was “Do you understand why you were born?" In fact, my birth was a remarkably unlikely event; a miraculously random event. I would have never even been conceived or born if my mother or father had made a left turn one day in that forest as opposed to a right turn. So, my birth was viewed as a miracle, and as an event with profound and specific purpose, meaning and destiny. It was clear, through both direct verbal and nonverbal communication, that the purpose of my birth, and the purpose of my life, was to grow up to become someone who must have such a profound impact on the world, particularly in the areas of suffering and living despite the reality of death, that my achievements would ultimately justify my parents' survival. It would allow my parents to declare "You see, it was right and necessary that we had to survive, so that there would be a Velvel Breitbart in the world!" Velvel being my Yiddish name. You see "Destiny" and God's plan, were critical and unalterable forces determining their survival, freeing them of any guilt, and bringing meaning to a meaningless world. And with this purpose determined for my life, the sense of freedom to choose to create my life based on my choices and unique to my passions appeared lost, and not even an option. I was to be the "Redeemer." The Redeemer of Grand Street. 


\section{Dread and the Denial of Death}

The second significant loss was the loss of "my ability to utilize the defense of Denial of Death." I've lived with a sense of "Dread" my entire life. A constant state of angst and awareness of the inescapable reality of death characterized by frequent episodes of panic, death terror, and a profound fear of death-specifically "non-existence." Likely this was due to the constancy of the presence of death which was pervasive throughout my childhood and formative years. A constant state of death terror. Stories of my childhood were stories of death; relatives and how they died, relatives who died young and never had the chance to create lives; hundreds and hundreds of relatives who could never be born because of the mass genocide that ended the lives of their potential parents. Non-existence was particularly overwhelmingly disturbing to me, likely due to my sensitivity to the fact that I myself could easily have never existed. In addition, the freedom to create the authentic essence of my own life from the reality of my existence had often felt out of my reach. Existence was precious to me and so much more evanescent. In my childhood home, when the telephone would ring after $10 \mathrm{pm}$ my parents would be visibly startled and shaken; "Who died?" was the question. No one would call this late unless someone had died.

Death was a constant fact of life, a reality. It was in the air we breathed in the Grand Street apartment. But, it followed me wherever I went as well. Age 4, nursery school. Playing with blocks, finger painting, feeding the fish and turtles in the aquarium. It was a religious Jewish nursery school. All boys. All my classmates were like me, children of Holocaust survivors. Many had parents who were older than mine; parents who had lost their first families and now had started new families post-Holocaust. Later in High School when I would visit my classmates in their apartments to do homework together, I would notice the difference between their parents and mine. My parents were young enough to still have hopes and dreams and the will to risk living and loving. My classmates' parents struck me more as ghosts sitting on plastic covered sofas in their living rooms, joyless and empty. Nursery school was my first experience being separated from my mother for any extended time period, and I handled that separation pretty well I thought. Until one day in the supply closet. It was Nathan Sheff and I who wandered into the open supply closet. Nathan Sheff, the rowdy troublemaker, who today is an esteemed Orthodox Jewish Rabbi and Scholar, coaxed me into the supply closet to explore. There it was, on the countertop, just at eye level for us. A small tin can, on its side, with the dry granular contents spilled out onto the wooden countertop. "What do you think that is?" asked Nathan. "I don't know" I said. "Well, why don't you taste it and see!" prodded Nathan. I wet my index finger and pressed it against the spilled contents which felt a bit like coarse, diy oregano with somewhat nondescript larger granules. I placed that index finger into my mouth to taste it. No taste, nothing particularly notable. "That's Turtle Food! It's poison! You're going to die!" screamed Nathan. Panic! Terror! Death! The moment had finally arrived! Before I had even had the chance to become who I might have hoped to become! Dead, before I was born!

The resulting death terror was paralyzing, manifest as separation anxiety. I refused to leave my mother's side. My mother tried everything! Well, not a doctor or therapist, but she did take me to a woman who read the future by ladling molten lead onto a pot of water and interpreting the images. Apparently, it revealed that I was a sensitive child who was veiy 
good at reading people's emotions and empathizing with them. It also revealed that I would in fact grow old, marry twice and die of a "large heart." This didn't help. The solution did however arrive in the form of Rabbi Kaminsky, the grandfather of one of my nursery school classmates. I have patients who arrive for their first visit with me and sigh this intense sigh of relief. I usually ask why, and they all say the same thing, "You look the way a shrink should look-that's really veiy reassuring!" Rabbi Kaminsky was a "Sage." A wise Rabbi and Talmudic Scholar who looked the way a Sage should look. He was dressed in Hasidic black garb, a rotund belly, a broad long white beard, and a content smile. An Orthodox Jewish Buddha. Rabbi Kaminsky was sitting in an overstuffed chair and placed both of his hands on my shoulders as I stood close to him, facing him, hoping for peace and relief from my intense panic. He took out a gold chain with a small mezuzah attached to it, a necklace for me to wear. He said the Rabbi's Blessing with one hand on my head. He blessed the mezuzah necklace and then informed me of the power of this talisman he was about to place over my head for me to wear around my neck at all times. "Velvel, as long as you wear this mezuzah nothing can harm you! You are protected by God." A wave of relief poured over me. Calm, peace, protection. Like the lyrics of the John Mayer song "I am invincible, as long as I'm alive!" When I somehow lost that mezuzah a year or so later, I didn't seem to need it. But death lurked just beneath the surface as a constant dreadful companion.

\section{Healing through Choice, Transcendence, and Forgiveness}

I was not the only "Redeemer" raised on Grand Street. As you might imagine, most of my classmates in the Orthodox Jewish all boys school I attended came from Holocaust surviving families. They, like me, were also raised with the mandate and expectation that their lives' only purpose was to provide justification for their parents' survival. This was a burden for so many of us. Often it was a "Crushing Burden." This crushing burden in fact served to demoralize and embitter many of my friends and classmates, sometimes in dramatic ways. It is a tall order to impact the world so profoundly that it serves to redeem your beloved parents. Some turned tragically to drugs. Many became dentists!

For me, this burden became an inspiration. I realized that in fact I was no different than any other human being who comes into existence with a set of biological and genetic characteristics, socio-economic and cultural realities, born into a specific time and family not of our choosing. We are given this reality and framework for our existence that we cannot change or alter. All we can do is choose how we respond. All we can do is to realize that our ultimate freedom is to choose how we think about any circumstance or limitation and that we also have the freedom to choose our attitude towards all the realities, and limitations that life and existence present to us, and that we confront in the process of creating our lives. I went to medical school, rather than choosing the path to become a creative writer and poet, partly because my mother threatened to stab me with a kitchen knife when I suggested that perhaps I would not take the medical college admissions test. As I fled from the kitchen down the hallway to lock myself in the bathroom for safety, I suddenly had an epiphany. I believe I heard the voice of God advising me "Bill maybe you should become a doctor!" In medical school, I fell in love with medicine, and with psychiatry. I trained in both internal medicine and general psychiatiy, getting board certified in both. I didn't fully understand why I was interested in that interface of medicine and 
psychiatiy. Then I found myself doing a fellowship in Consultation Liaison Psychiatry/ Psycho-oncology at Memorial Sloan Kettering Cancer Center with Jimmie Holland (who became my mentor for 33 years). I didn't know exactly why I chose to place myself there. In 1984, the first year of my fellowship, the AIDS epidemic exploded, and there I was face to face with death; face to face with young men my own age, dying horrifically with no effective treatment available. Suffering, Death, Living in the Face of Death. How was it possible to live a life, keep creating a life with the knowledge that death was very, veiy real and close by. It seemed familiar. It was in fact my own personal lifelong dilemma and struggle. I grew up tiying to understand how to live a mortal life. How do you live knowing death is real, inevitable and could happen at any moment. I began to realize that I had placed myself intentionally at Sloan Kettering. I had placed myself at that nexus between life and death. In that liminal space. I was there breathing the same air as my patients who were facing death, in veiy real and immediate ways. I was there to learn how to find meaning in life and how to find meaning in death. I was there to learn how to forgive myself for being human, mortal, vulnerable, imperfect and never truly being able to reach my fullest possible potential or be completely unique and authentic, To relieve my existential guilt through forgiveness, and to create a life that approached authenticity by transcending my own personal existence and connecting to something greater than myself: the suffering of my patients, the suffering of humanity. Out of a need to relieve suffering I sought to understand the causes of suffering, the fear of death, the causes of loss of meaning, and then to develop interventions to ameliorate the suffering and help patients heal. What evolved was a clinical and research career that allowed me to utilize the creative energy and talents I possessed as a poet. I studied suffering in all its dimensions, particularly the factors that lead patients to want to rush into death to escape suffering. I discovered the role and healing power of meaning from Viktor Frankl and developed Meaning-Centered Psychotherapy for cancer patients. This intervention has eased the suffering of tens of thousands of cancer patients around the world, with more being helped every day, around the world.

On my 50th birthday, my mother wrote me a message on the birthday card she gave me. Her message read "My Dearest Son. I know that when you were growing up we had terribly unrealistic expectations of what we wanted you to accomplish with your life. It was an impossible task we gave you. Son, you've exceeded all our expectations. You can relax now. You've done more than enough." When I read that message, I was grateful to my mother, and I thanked her for giving me life; for all the love and gifts both she and my father had given me. But then I went further. I told my mother "No, it's not time for me to stop, you see I'm not doing this for you anymore, I haven't been for a while. I am doing it because it is who I am, and I have not yet finished becoming me." I had broken wings and learned to fly and now was my moment to arise.

And in these days of the COVID pandemic, I find death close every waking moment.

I grapple daily with accepting my mortality, accepting death when it comes, and being grateful for this life I have been given and created as my own (a Legacy Given and now a Legacy Lived). A few weeks ago, at the height of the pandemic in New York City, I woke up for yet another day of work at home, seeing patients via telepsychiatry and having administrative meetings on Zoom. It was early morning and I walked into the kitchen to 
make coffee. I found myself talking out loud to my deceased parents. "Mom, Dad, can you believe this is really happening?" This COVID pandemic reminded me of my parents 3 years of hiding in the forest to save their lives. The parallels struck me, but the differences were a necessary reality check. My parents never had a change of clothes or a shower. They went without food for weeks. They slept on the forest floor and were fearful every moment that they would be found and killed. A far ciy from the comforts of my apartment, delivered food and medications, internet, computers, cellphones, and Netflix. I continued to talk to my parents and found myself overwhelmed with gratitude. The fact that I had the miraculously rare and random opportunity to exist (and not die before I was born) brought tears of joy. I was so grateful for the mere chance to experience existence as a human being. I could have easily never had this experience. "Mom and Dad, I am so grateful for this shot at life, the opportunity to live and create a life and the chance to find love and joy. It's all been worth it, no matter how long or short, no matter what tragedies or joys befall me; at least I had this rare, unexpected opportunity to live my life as a human being!"

\section{Reference}

McCartney P and Lennon J (1968) Lennon-McCartney: Blackbird. London: The Beatles Apple Records. 